\title{
Las cofradías de Perú en la modernidad y el espíritu de la contrarreforma
}

\author{
Joaquín Rodríguez Mateos \\ Archivero del Cuerpo Facultativo \\ Archivo General de Indias
}

El estudio de la cofradía, como institución, entronca con el de las diversas formas de asociación voluntaria, como un medio de integración en el seno de cualquier sociedad de los diversos grupos humanos que la componen, constituyéndose en vehículo de participación en el sistema cultural. Las características y las formas de organización que adquiere para ello van a conferirle una entidad propia que la convierta en una institución permanente y vigente a lo largo del tiempo; serán su flexibilidad y su adaptabilidad a la estructura social las que la hagan triunfar tanto en la Península como en el Nuevo Mundo, vertebrando ritual y simbólicamente al conjunto social.

A un tiempo, como expresión de la praxis religiosa contrarreformista, se convirtió en uno de los fenómenos más impulsados por las órdenes religiosas en su misión adoctrinadora, sirviendo como una de las principales armas de evangelización en las tierras americanas. Su parafernalia teatral sirvió de elemento de atracción popular, captando la sensibilidad y las pulsiones sociales de la Modernidad hispánica, a un tiempo que fueron, de forma paralela, celosamente controladas por la lglesia institucional, robustecida después de Trento.

La cofradía, como institución social, ha venido recabando de tiempo a esta parte el interés y la atención de los científicos sociales. Son la amplitud de sus funciones, su grado de variabilidad y su capacidad de adaptación, las claves de su vigencia a lo largo del tiempo y del espacio. Las cofradías pueden ser estudiadas como unidades orgánicas o funcionales, abordables desde cualquier aspecto particular; pero será siempre un microcosmos que reproduce milimétricamente la estructura de la vida social, cualquiera que sea el grupo humano protagonista. Las características y formas de organización que adquiere para ello van a conferirle una entidad propia, que la convierta en una institución permanente y vigente.

Se ha hecho, por lo común, frecuente hincapié en ver a la cofradía indiana como una versión particular de esta, ya para entonces, tradicional institución hispánica. $\mathrm{E}$, incluso, hay quienes han querido ver una apropiación de la cofradía por los estratos indígenas para convertirse en un foco de supervivencia ideológica o sociopolítica frente a los colonizadores hispanos. No diríamos nosotros ni lo uno, por simplista, ni lo otro, por arriesgado. 
Los orígenes y las motivaciones en el Nuevo Mundo fueron, en parte, distintos a los de la Península. La estructura social americana fue también diferente a la española. Más nos inclinamos, por tanto, en buscar precisamente en esa variabilidad que caracteriza a la cofradía, por su capacidad de adaptación social, las claves que expliquen su triunfo en América y el enorme desarrollo que adquirió, al igual que triunfó en España por encima de las barreras de los oficios, las clases o las etnias. No es válida para nosotros una explicación que se fundamente de forma exclusiva en un surgimiento espontáneo y autónomo de las cofradías, al modo y estilo de los patrones peninsulares, a pesar del buen número de ellas creadas por los emigrantes españoles. Tampoco lo es la que lo haga solamente basada en la intencionalidad eclesiástica de su origen; Charles Gibson, en su análisis del caso mexicano, creía ya "que la imposición en sí es insuficiente para explicar su desarrollo". ' De este modo, aunque vamos a observar en los ritmos evolutivos y en los procesos de cambio un cierto paralelismo entre ambas márgenes atlánticas, dentro de las estructuras de la cultura hispánica de la Modernidad, tales similitudes no deben llevarnos a extraer conclusiones apresuradas y equívocas que nos hagan tomar el fenómeno cofradía, en su conjunto, como una realidad única de características comunes tanto en las tierras de Castilla como en los altiplanos andinos.

Vamos a delimitar así el espacio de trabajo y situarnos en un área geográfica determinada, Perú, y en un tiempo concreto, la Modernidad. El Arzobispado de Lima ha sido, posiblemente, el de mayor extensión que haya existido. El arzobispo Loayza, de quien se decía estar muy gastado y cansado, por ser como es hombre anciano, se excusa a Su Majestad de no poder recorrer el territorio de su Arzobispado: en algunas partes medía casi 200 leguas, y los pueblos distaban hasta 60 y 80 leguas unos de otros. ${ }^{2}$ El accidentado relieve de las comarcas andinas y las altiplanicies incas supuso igualmente un eterno problema a los colonizadores, quienes buscaron asentamiento más estable en las llanuras litorales, fundando allí su capital, la Ciudad de los Reyes o Lima.

En el año 1564, en el que Felipe II impone en sus reinos el Concilio de Trento, tenía Lima ocho obispados sufragáneos, que iban desde

1 Gibson, Charles: Los aztecas bajo el dominio español. México, 1964.

2 Villegas, Juan: Aplicación del Concilio de Trento en Hispanoamérica (1564-1600). Provincia Eclesiástica del Perí. Montevideo, 1975, pág. 177. 
Santiago de Chile a Nicaragua. Lógicamente, la gran extensión territorial de la provincia eclesiástica del Perú nos ha obligado a centrarnos, de forma fundamental, en la demarcación del propio Arzobispado de Lima como diócesis metropolitana, aunque atendiendo al mismo tiempo al resto de las demarcaciones episcopales andinas. No obstante, las escasas fuentes documentales con las que contamos para este período - época aún de desarrollo y consolidación de la nueva sociedad colonial- nos mueven a prestar máximo interés a cualquier información detectada a este respecto referente a toda la zona del antiguo reino del Perú.

Es precisamente en esta zona y en esta época donde hemos querido analizar la presencia y el papel ejercido por las cofradías, en el espíritu que supuso la puesta en práctica del Concilio de Trento, con todo su aparato ceremonial y adoctrinador. Incluso deberíamos decir mejor, de la multiplicidad de tales papeles. Su herencia directa será el panorama que encontraremos establecido en las tierras andinas a comienzos del siglo del Barroco, y que se mantendrá a todo lo largo de la Historia Moderna.

\section{Una expresión contrarreformista}

Las formas de la vida social española se orientaron en el Nuevo Mundo de modo fundamental hacia el sistema urbano, como receptor principal de la población hispana; se condicionarían así desde un principio sus expresiones religiosas dentro del modelo peninsular. Son las cofradías de españoles, en este marco ciudadano, las que mejor expresan el espíritu de la segunda mitad del Quinientos, y más tarde de los postulados contrarreformistas: la conducta ascética, la simbología ritual, el corporativismo religioso, la ayuda mutua, son características que llevan consigo los emigrantes peninsulares que se asientan en las tierras ultramarinas. Con ellos emigran sus devociones y sus símbolos, su sensibilidad y sus mecanismos de conducta. Irán apareciendo así cofradías de advocaciones tradicionales de la metrópoli, tales como las de la Vera Cruz, del Cristo de San Agustín, de la Antigua o de Jesús Nazareno, que para estas fechas comienzan en Sevilla su período de esplendor.

El fomento del culto sacramental, la importancia de devociones e imágenes como vehículos de salvación, la práctica de los sacramentos, el desarrollo de las penitencias públicas, la fundación de obras pías, son postulados todos contrarreformistas que encontraron un firme puntal en 
las cofradías. Sirvan como botón de muestra las palabras del propio arzobispo de Lima:

"Frequentan los cofrades españoles los sacramentos de la confesión y eucharistía que, si no lo fueran, por ventura no lo hizieran. Las del Sanctísimo Sacramento acuden los Jueves Sanctos con çera para los monumentos, y todas el día y octava del Corpus acompañan con ella y con insignias las proçesiones, y otras generales que se hazen entre año, aunque en éstas no llevan insignias. También acompañan algunos entierros". 3

No obstante, el auténtico desarrollo de la cofradía en Perú viene de su utilización como instrumento doctrinal en manos del clero frente a la población indígena. La puesta en práctica del aparato conciliar suponía una auténtica pedagogía combativa que velara por la difusión y la pureza de la doctrina, encontrándose en las cofradías una de sus armas más efectivas. De ahí el fomento y el impulso que experimentaron en el último tercio del siglo por parte de la jerarquía eclesiástica, orientándose en el caso peruano de manera principal hacia las clases subalternas y los sectores religiosamente indigentes. Es el propio arzobispo Toribio de Mogrovejo -quien consolidó la organización de la Iglesia peruana siguiendo los postulados trentinos - uno de los primeros impulsores del fenómeno de fundación de cofradías en su Arzobispado, como nos pone de manifiesto Olinda Celestino. ${ }^{4}$ Así se describen por los propios religiosos las cofradías limeñas de indios y negros:

"El fin de estas cofradías es el que traen escrito en el nombre y apellido: llámanse de la doctrina cristiana, por que lo que en ellas se profesa es aprenderla e ynstruir a los nuevos christianos en ella. A este fin se ordenan las juntas que tienen los domingos todos del año en nuestra yglesia, donde los padres que para este ministerio están dedicados les enseñan el cateçismo, y declaran las cosas de nuestra santa fee, y dan orden en sus vidas y costumbres, enseñándoles cómo han de bivir christianamente". 5

La propagación de la fe y el adoctrinamiento, al tiempo que se consolidaba el cuerpo dogmático de la Iglesia, se revelaron como el autén-

3 Ibidem.

4 Celestino, Olinda y Meyers, Albert: Las cofradias en el Perú. Región central. Frankfurt, 1981, pág. 111.

5 AGI, Lima, 34, libro 6, n." 41. Relación adjunta a la carta del virrey del Perú a S.M., acerca de las cofradías de indios y negros existentes en los conventos y monasterios de Lima. Joseph Tiruel, rector de la Colegial de San Pablo, de la Compañía de Jesús. II de abril de 1603. 
tico motor de la Contrarreforma; de este modo, por medio de la cofradía se podía conseguir el cuidado de las imágenes, de las iglesias, de los hospitales. Foster afirmaba ya que "los frailes y los curas fomentaban la organización de cofradías sacramentales entre los indios como un medio de propagar la fe, cuidar de las imágenes de las iglesias y asegurar pintorescos festivales religiosos", ${ }^{6}$ lo que, según la mentalidad española, "servía para 'aficionarlos" más al culto cristiano". ${ }^{7}$ La cofradía prestó de esta forma, con su multiplicidad de funciones, un importante servicio a la Iglesia en las comarcas andinas como una punta de lanza de su penetración espiritual y organizativa. Ellas serían las principales mantenedoras de los actos públicos en su labor adoctrinadora y ejemplar, proliferando de su mano las funciones religiosas, las procesiones y las fundaciones pías. En 1613, el criollo Felipe Huaman Poma de Ayala escribe en su Nueva Corónica y buen gobierno:

“...para que veays que son cristianos y tienen fe los indios, y tienen capillanía y altares y hermita en sus estancias y chácaras; y tienen ymágenes y bultos y hornamentos y pendones, y muchos seriales y candelas de sera, y con ello priostes, mayordomos, munidores y fiscales, y cofrades cincillos, y ermanos, y veynti y quatro; y en la fiesta mucha dansa, y baylles, y taquíes a costa de ellos para honrrar la dicha fiesta ... Después dizen que los yndios son bárbaros y no son cristianos: es al revés de los que dizen los españoles avarientos deste reyno...". ${ }^{8}$

Recogiendo este espíritu catequético, el propio arzobispo de Lima escribe al rey por esa misma fecha, argumentando que

"las cofradías de yndios y negros son de mucho fructo, porque se occupan en actos virtuosos, como son sermones y doctrina, en que los padres de la Compañía se esmeran. Y no hallo en qué devan estas cofradías ser mejoradas, como quiere saber V.M., sino que se estén así y se continuen los buenos efectos y devoçión de ellas". 9

En todo ello, la parafernalia teatral y ritual de la religiosidad barroca venía a ejercer un importante papel como instrumento para la atrac-

6 Foster, George M.: "Cofradía y compadrazgo en España e Hispanoamérica", en Guatemala Indígena, vol. I, n." I, 1961.

7 Celestino y Meyers: Las cofradías en el Perú..., pág. 106. pág. 920.

8 Huaman Poma de Ayala, Felipe: Nueva Corónica y buen gobierno. (1613). Paris, 1936,

9 AGI, Lima, 301. Carta del arzobispo a S.M., fol. 2 v." 
ción de la sensibilidad indígena, siguiendo la sintaxis de un lenguaje simbólico y cercano. El dirigismo eclesial de las manifestaciones externas incidía siempre en este aspecto ceremonial, velándose tanto por el "ornato de la yglesia y culto divino ... para que los yndios gentiles se arrimen a convertirse", "10 como por la "decencia" de tales adornos. "También por estas fechas, el Inca Garcilaso relata cómo cada uno de los señores del Cuzco

"tenía cuydado de adornar las andas que sus vasallos avían de llevar en la procesión de la fiesta. Componíanlas con seda, oro y muchas ricas joyas, con esmeraldas y otras piedras preciosas. $Y$ dentro, en las andas, ponían la imagen de nuestro Señor o de nuestra Señora, o de otro santo o santa de la devoción del español o de los yndios, sus vasallos. Semejavan las andas a las que en España llevan las cofradías en las tales fiestas". ${ }^{2}$

El elevado grado de acogida y participación que tuvo esta sensibilidad festiva y comunitaria por parte de la población indígena de las Indias, en general, se refleja en algunos textos de sus contemporáneos, como en esta cita de fray Juan de Grijalba:

"aunque los españoles fueron aficionados a las procesiones, los indios venían a resultar en este punto sus maestros". ${ }^{13}$

Se confundirían aquí la actividad misionera y las tareas de organización eclesiástica en una única realidad, que se difundía por el territorio conforme se desplazaba poco a poco la presencia del clero y se multiplicaba el número de los conventos de regulares, tras cuyos muros encontraban pronto origen nuevas cofradías. La expansión misional por el territorio peruano, en buena parte posterior a los decretos de Trento, estuvo acompañada frecuentemente por la creación de cofradías de forma pareja a la

10 AGI, Lima, 34, libro 5, fol. 184 v." Petición de Juan Fonte, 11 de Septiembre de 1601.

11 Estas preocupaciones hacían reparar a veces en la pobreza de las Iglesias de las doctrinas de indios como causa de mill faltas y de cosas yndecentísimas, con el peligro que suponía para una adecuada evangelización, donde cierto tipo de sincretismo cultural pudiera adquirir carta de autoridad en el seno de las expresiones religiosas: ... por que para hauerse de hazer procesiones se buscan mantas de yndios para mangas de cruzes, y para palio el dia de Corpus Christi ansi mismo se haze de las dichas mantas... AGI. Patronato, 248, R.11. Copia de un memorial dirigido al arzobispo de Lima el 4 de abril de 1585, acerca de la necesidad que padecían las iglesias y hospitales de aquél reino.

12 Inca Garcilaso: Historia General del Perú. Córdoba, 1617. Libro VIII, cap. I, fol. 275 r."

13 Crónica de la Orden de Nuestro Padre San Agustín entre las provincias de Nueva España. Lib. Il, cap. 6, fol. 72. 
erección de nuevas iglesias en las nacientes doctrinas de indios, lo que se desprende también de las palabras de algunos cronistas de Indias:

“...y de éstas [las procesiones] apenas hay pueblo que tenga religiosos donde no haya cantidad de ellas". ${ }^{14}$

Charles Gibson, en la obra citada, hacía notar ya que "la cofradía representa, en su mayoría, una respuesta tardía al cristianismo", siendo "los años de mayor vigor los posteriores a 1600". Aunque el objeto de su análisis es la zona azteca, esto se hace especialmente válido para Perú, teniendo en cuenta fundamentalmente tanto la tardía pacificación del territorio como el consiguiente retraso en el afianzamiento de la organización eclesiástica. De tal forma, los decretos tridentinos sobre la reforma "no prestaron a las jóvenes iglesias de la provincia eclesiástica del Perú el servicio de una renovación. Simplemente las iglesias eran muy nuevas para poderse reorganizar. Más bien los decretos sobre la reforma venían a ayudar a estos obispados a fundarse y organizarse con solidez". ${ }^{15}$ No obstante, estas precisiones se hacen más válidas para el ámbito rural que para las ciudades, donde el implante de las cofradías es bastante temprano.

\section{La doble caracterización de la cofradía indiana}

Para el estudio detallado de la cofradía en Indias, como institución concreta, tenemos que partir desde un comienzo de una distinción conceptual entre las cofradías de ámbitos urbanos, cualquiera que sea en principio el estrato étnico que las componga, y las de zonas rurales, asociadas a pueblos, doctrinas y comunidades indígenas. Sus motivaciones, sus fines y sus ritmos de desarrollo obedecían a fuerzas diferentes y a intereses distintos.

\section{La cofradia en el medio urbano}

La eclosión de las cofradías comienza siempre en Indias en los núcleos de población española, con su orientación eminentemente urbana, y parece convertirse en un mecanismo religioso y asociativo consustancial a la misma. De aquí se difunde el modelo, impuesto o espontáneo,

14 Mendieta, Fray Jerónimo de: Historia Eclesiástica Indiana, 1585. Libro IV, Capítulo 20.

15 Villegas, Juan: Aplicación del Concilio... pág. 71. 
alcanzando y adaptándose a todas las capas sociales y los grupos humanos por el extenso territorio andino. Incluso se ha afirmado que "allí donde residiesen españoles (en cualquier cantidad) se establecieron cofradías, tanto ladinas como indígenas". ${ }^{16}$ De la mano de las órdenes mendicantes, que comienzan a multiplicar sus conventos, empieza a aparecer una extensa lista de cofradías, iniciándose por la propia ciudad de Lima. Gran parte de ellas surgen con una finalidad benéfico-asistencial que era ya habitual en las urbes castellanas desde el siglo anterior, siendo, por ejemplo, numerosas las cofradías hospitalarias, como pone Foster de relieve: "Muchas estuvieron asociadas con órdenes religiosas, y tenían como función principal el cuidado y sostenimiento de los hospitales". ${ }^{17}$ De la misma forma desarrollaron ciertas tareas de caridad pública unidas a la actividad de las parroquias, lo que lleva incluso el virrey don Francisco de Toledo a las Ordenanzas para la ciudad del Cuzco:

"Item, que en cada una de las dichas parroquias haya una cofradía de la Caridad, en la cual el día de la advocación se elijan dos mayordomos, que sean los indios más hábiles que hubiere; los cuales aquel año de su mayordomía entiendan en hacer acudir las gentes a las casas de caridad, principalmente a que sepan e inquieran a los enfermos que haya en la dicha parroquia para que si fueran pobres los hagan llevar al Hospital, y den noticia al cura para que los visite y haga que los velen..... ${ }^{18}$

Este carácter mutual-asistencial, que se convirtió en una de sus funciones tradicionales, se expresó habitualmente a la hora de la muerte: a cambio de una limosna o un canon establecido, la cofradía asumía las responsabilidades de organización del ritual funerario del cofrade o encomendado, aportando los elementos materiales necesarios para el mismo, por lo común el paño mortuorio, cera y responso, así como el acompañamiento del cuerpo por los demás cofrades. Son numerosas las mandas testamentarias donde se especifica la voluntad de los testadores de ser atendidos en su muerte por una u otra cofradía, a la que podían o no haber pertenecido en vida. 19

16 Orellana, Sandra L.: "La introducción del sistema de cofradías en la región del lago Atitlán en los altos de Guatemala", en América Indígena, Vol. XXXV-4, 1975.

17 Foster, George: "Cofradía y compadrazgo...".

18 Ordenanzas de D. Francisco de Toledo para la ciudad del Cuzco. 18 de Octubre de 1572. Título XXVI: De las Parroquias. Publicadas por Roberto Levillier. Madrid, 1929, pág. 112.

19 Los numerosos testamentos que se encuentran en los Autos de Bienes de Difuntos conservados en la Sección Contratación del Archivo General de Indias, recogen una buena muestra de cuanto decimos. 
Según el testimonio del padre Cobo, las cofradías de españoles fundadas en Lima fueron, por orden de antigüedad hasta 1630, las de la Veracruz, la Piedad, el Santo Crucifijo de San Agustín, la Soledad, la Redención, el Niño Jesús, la de Nuestra Señora de Loreto y la de Jesús Nazareno, orden que guardaban en la procesión del Corpus Christi. En 1619, según la relación del Arzobispo de Lima, ${ }^{20}$ eran 61 las cofradías existentes en la ciudad, de españoles, negros e indios, igualando, si no superando, el número de las existentes en la Sevilla de la época. El padre Cobo cita para el mencionado año de 1630 el número de 57 cofradías las fundadas en la ciudad: 25 de españoles, 13 de indios y 19 de negros y mulatos. Otras ciudades o villas de población hispana reunieron igualmente un buen número de cofradías: en el puerto del Callao, 20; en la villa de Ica, 11; en la ciudad de Huánuco, 10; en la villa de Cañete, 5.

Creemos importante atender a la composición social de la población española en América para poder encontrar explicación a ciertas actitudes reflejadas en las cofradías. En los comienzos de la colonia, conquistadores, aventureros y buscadores de fortuna crearon ciudades, se construyeron mansiones y se adjudicaron bienes y haciendas. Manteniendo unos patrones de conducta y ostentando un sistema de valores propio de la hidalguía pretendieron conseguir y obtener lo que en España les estaba vedado: prestigio, status y reconocimiento social. En palabras de Pilar Sanchiz, "este supremo ideal temporal determina el comportamiento y actitudes de estos individuos. (...) Estos hidalgos de ultramar adquieren en verdad su importancia al formar, al consolidar su grupo social bien diferenciado por estas características: creencias y valores compartidos, e interacción ajustada a unos modelos, que les hacen poseer, entre otras cosas, una conciencia de clase". ${ }^{21}$ Ello motivó que estos sectores emergentes en la naciente sociedad colonial, destacados por sus servicios a la Corona en la conquista, pacificación y organización del territorio, fundaran en los primeros años de la colonia una serie de cofradías que respondían a las propias de clases altas de la Sevilla de la época - la Vera Cruz, la Soledad, Jesús Nazareno- y que se revistieran de unas exigencias explícitas, no ya sólo de limpieza de sangre sino incluso de hidalguía, que

20 Bernales Ballesteros, Jorge: "Las Hermandades de Sevilla y su proyección en América", en Apotheca. Revista del Departamento de Historia del Arte de la Universidad de Córdoba, n." 6, 1986.

21 Sanchiz Ochoa, Pilar: Los hidalgos de Guatemala. Sevilla, 1976, págs. 7 y ss. 
ni siquiera se recogían en los Estatutos de las cofradías peninsulares. De la pertenencia y el servicio a la cofradía se derivaría el prestigio social y el status. Es el caso, de forma explícita, de la cofradía de la Vera Cruz de Lima, plasmado en las Reglas aprobadas en 1570 por el arzobispo Loayza, en las que se preceptuaban unos requisitos para su pertenencia a la misma que garantizaran la posición social y ritual de sus cofrades. En general, era frecuente encontrar por las diversas ciudades peruanas cofradías integradas por los altos estratos sociales, agrupados en torno a un símbolo que confería una identidad de estamento. Así se pone de manifiesto, por ejemplo, en la cofradía de Nuestra Señora del Rosario, fundada en el Monasterio de Santo Domingo de la ciudad de San Juan de la Frontera de Huamanga, de la que se decía que estaba servida "con toda la gente prinçipal del pueblo". ${ }^{22}$

El arraigo experimentado en la misma ciudad de Lima por las cofradías haría superar pronto las barreras de las clases sociales, los oficios y las etnias. Los barrios, como San Lázaro o San Marcelo, irán contando poco a poco con sus cofradías, al tiempo que irán surgiendo algunas de vinculación profesional o gremial: la de San José, con su capilla en la Catedral, pertenecerá a los oficiales carpinteros; la de San Crispín y San Crispiniano, instituida también en la Catedral, agrupaba a los zapateros, que recibían del Cabildo de la ciudad el monto de la veeduría de los cordobanes; la de San Eloy, en San Agustín, era la cofradía de los plateros; la de San Joaquín, establecida en Santa Ana, estaba fundada por los pescadores indios; y en el puerto del Callao estaba fundada la de Santa Bárbara por los artilleros. Jorge Bernales nos cita igualmente la cofradía del Cristo de Burgos, fundada a fines del XVI por los escribanos de la ciudad, a semejanza de la hermandad homónima de Sevilla, así como lo fue la de la Soledad, en 1604, por los barberos y cirujanos. ${ }^{23}$

Bien por imitación o emulación, el mundo de la ciudad se llenó pronto de cofradías étnicas que seguían los patrones de sus convecinos españoles. Obviamente, la gran separación racial y étnica imperante en Indias motivó el que sus cofradías fuesen de carácter cerrado en torno al propio grupo racial, creando una segregación ritual que contribuía a la jerarquización de la sociedad. Indios, negros y mulatos fundaron sus res-

22 AGI, Patronato, 294, N." 15, fol. 8 r." Relación de San Juan de la Frontera de Huamanga. 22 de febrero de 1586 .

23 Bernales Ballesteros: "Las Hermandades de Sevilla ...". 
pectivas cofradías, suponiendo a comienzos del siglo XVII prácticamente la mitad de las existentes en la ciudad. No sólo compartían hábitat, sino igualmente unos ritmos de conducta socialmente pautados que cristalizaron en cofradías al modo español. Sirvan como ejemplo la cofradía de Nuestra Señora de Agua Santa, de negros, en el monasterio de la Merced, que hacía su procesión de sangre el Viernes Santo; o la de Nuestra Señora de los Reyes, fundada en el convento de San Francisco por negros de diferentes castas, de los que se decía que

"sustentan la dicha confradía con mucho lustre y adorno, siendo ésta una de las mejores y más bien servida de quantas ay en esta ciudad por el cuidado de los dichos morenos". ${ }^{24}$

Este carácter en pugna de las cofradías étnicas frente a las de blancos en la realización de sus actividades, celebraciones y rituales - una "lucha simbólica con los dominadores", en palabras del profesor Isidoro Moreno- ${ }^{25}$ era una constante a lo largo del siglo XVI, originando, tanto en Indias como en la Península, grandes alabanzas a la devoción y religiosidad de los estamentos de color por parte de cronistas e historiadores de la época. En el fondo, se trataba de la única forma que tenían tales etnias de superar ciertos recelos sociales hacia su integridad y pureza religiosa, recelos disfrazados de religiosidad que escondían otros más profundos de fuerte marginación social.

La gran cantidad de cofradías existentes en Lima suponía un fenómeno económico de indudable alcance. Sus ingresos procedían de las rentas de censos y otras posesiones que gozaban un buen número de ellas, así como, fundamentalmente, de la extendida práctica de la limosna, fenómeno que analizaremos con más detalle; a este efecto era frecuente encontrar mesas petitorias en las puertas de las iglesias y conventos, como las que se instalaban en San Francisco o Santo Domingo. Eran también las cofradías, principalmente las de mayor prestigio social, depositarias de las mandas y donaciones realizadas hacia ellas por sus cofrades, encomendados, bienhechores o simples fieles, y que aparecen recogidas con

24 AGI, Lima, 301. "Relación de las ciudades, villas y lugares, parrochias y doctrinas que ay en este Arçobispado de Lima, de Españoles y de Indios (...) y de las Cofradías y Hospitales que ay en los dichos lugares, sus rentas y advocaciones". Acompaña a la carta del arzobispo de Lima a S.M., de 15 de abril de 1619.

25 Moreno Navarro, Isidoro: La Semana Santa de Sevilla. Conformación, mixtificación y significaciones. Sevilla, 1992 (3." Edición), pág. 124. 
alguna frecuencia en testamentos y últimas voluntades como expresión de la sensibilidad pietista ante la concepción barroca de la muerte.

En 1619, las cofradías del Santísimo Sacramento, con 3.200 pesos, de la Limpia Concepción, con 2.500 pesos, y de las Animas, con 1.000, todas ellas fundadas en la Catedral, eran las que gozaban de mayores rentas provenidas de sus posesiones. Por contra, la mayor parte de las cofradías gozaba de una media de trescientos a cuatrocientos pesos anuales, recogidos en limosnas. A pesar de que existían algunas de ellas con muy escasos o casi nulos ingresos, las limosnas eran para otras una muy importante fuente de financiación: la cofradía de las Animas de la Catedral recogía al año catorce o quince mil pesos; la Vera Cruz, de Santo Domingo, dos mil; la del Rosario, de este mismo monasterio, unos mil cien, mientras que la ya citada de Nuestra Señora de los Reyes, del convento de San Francisco, recogía unos mil pesos anuales.

El propio virrey expresa su personal valoración económica de las cofradías de la ciudad, al escribir a Felipe II en 1590:

“...algunas muy ricas, como son la del Santísimo Sacramento, la de las Animas de Purgatorio, la de la capilla de las cárceles de el Audiencia y Ciudad, la del Rosario y otras...". ${ }^{26}$

La mayor parte de estos ingresos eran empleados en cera, aceite para las lámparas de los altares, adornos y servicio para los mismos, las fiestas patronales o de instituto, y las misas encargadas por las cofradías a los párrocos o religiosos de los conventos. En 1619, el coste de una misa rezada oscilaba en Lima entre los ocho y los diez pesos, lo que puede dar indicios del volumen económico revertido hacia el clero, y que supondría su principal fuente de ingresos. Ocasionalmente, y atendiendo a la finalidad del instituto de la cofradía, estos capitales se destinaban también a otras obras pías diversas, como casar huérfanas - casos de la cofradía de Nuestra Señora del Rosario, del monasterio de Santo Domingo, o de la Limpia Concepción, del de San Francisco- o bien rescatar cautivos, como la que estaba fundada con este fin en el monasterio de la Merced.

De la misma forma, las cantidades económicas vertidas hacia las procesiones eran origen de celebraciones suntuosas, como pone de manifiesto, una vez más, el testimonio del padre Cobo:

26 AGI, Lima, 32, libro I, n." 36, fol. 122 r." El virrey de Perú a S.M., I de mayo de 1590. 
“...costosas andas, algunas de plata; ricas imágenes de bulto que sacan en ellas; sus pendones de seda, cruces y cetros de plata, con otras cosas de adorno y riqueza, particularmente con tanta cantidad de cera que pone admiración ver el gran consumo que hay en ella y la liberalidad y magnificencia con que en esta república la gastan sin reparar en el precio, aunque sea muy excesivo". 27

Las procesiones en Semana Santa, al margen de otras oficiales como la del Corpus Christi, aglutinaban a un corto número de cofradías en relación al de las existentes. A comienzos del siglo XVII, el número de cofradías penitenciales en Lima era tan sólo de siete, mientras que en el Callao existían tres, de un total de veinte. Estas cofradías, normalmente de sangre, estaban integradas en su mayoría por cofrades españoles, que expresaban así la sensibilidad ascética tan común de la cultura hispana del Barroco. A ello contribuyeron de forma importante, como también lo hicieran en la Península, las cofradías de la Vera Cruz, destacadas en la implantación y desarrollo de las penitencias públicas, cuya especial orientación era el mejor exponente de la sensibilidad ascética del Quinientos español. La salida procesional de estas cofradías tampoco se verificaba todos los años por cuanto los gastos derivados de la misma ascendían, aproximadamente, a unos 400 ó 500 pesos, aumentándose con ella considerablemente las cargas que debían soportar al cabo del año.

Estas cofradías de sangre corresponden en bastante medida a las de fundación más antigua, que son también las más destacadas social y económicamente de la ciudad. El Miércoles Santo salía la de Santa Catalina de Siena, de Santo Domingo; el Jueves Santo la Vera Cruz y la del Rosario - que era de negros- desde el Monasterio de Santo Domingo; también salía aquella noche, con gran número de disciplinantes, la del Cristo de Burgos, del convento de San Agustín. La Soledad partía el Viernes Santo desde San Francisco, siendo una de las más concurridas, a decir del cronista franciscano Córdoba y Salinas en 1650, pues convocaba a más de mil penitentes y recorría gran parte de la ciudad; ${ }^{28}$ mientras, ese mismo día lo hacían desde la Merced la cofradía de la Piedad - fundada hacia 1550 y denominada como cofradía de insignias- y la de Agua Santa, también de negros.

27 Tomado de Celestino y Meyers: Las cofradías en el Perú..., pág. 124.

28 Córdoba y Salinas, Fr. Diego: Crónica de la religiosísima Provincia de los Doce Apóstoles. Lima, 1651. Citado por Bernales Ballesteros: "Las Hermandades de Sevilla...". 
En El Callao, por su parte, las tres cofradías penitenciales eran las siguientes: la de los Nazarenos, del convento de Santo Domingo, el Miércoles Santo, viniéndole su nombre de las túnicas moradas y las cruces que portaban sus penitentes; la Vera Cruz, de la iglesia parroquial, el Jueves Santo; y la Soledad, de la misma parroquia, el Viernes Santo.

Este fenómeno mereció también la atención de las disposiciones conciliares, regulándose en ellas. Entre otros aspectos, incidieron todas en la prohibición de la disciplina pública para la mujer, al igual que sucedió en los sínodos diocesanos de Sevilla de la misma época:

"Y en la noche del jueves sancto en ninguna manera se consienta que mugeres se bayan diçiplinando en las proçessiones de los diçiplinantes, mas si algunas tovieren devoçión de haçer diçiplina, a solas y en secreto lo hagan en su casa". ${ }^{29}$

Huaman Poma de Ayala, en su obra ya citada, recoge al respecto ciertas opiniones y actitudes de los cofrades indios, que movieron a más de una queja de la jerarquía eclesiástica por cuanto se interpretaban como profanas en estos actos de pedagogía barroca socialmente ejemplares:

“...y el quien se deseplina dizen que a de comer carne el jueves santo, y para asotarse disen que a de estar muy vorracho...". ${ }^{30}$

\section{Las cofradías indigenas y la actuación del clero local}

Hemos visto anteriormente el proceso a través del cual comienza a desarrollarse y crecer la cofradía indígena en el último tercio del siglo XVI, de mano de la expansión misional por las tierras altas del Perú. Las doctrinas de indios que surgían por todas las provincias y obispados iban conformándose en células de organización y control de la población indígena, al cargo tanto del clero secular como de las principales órdenes. A esta situación contribuía en gran medida la aspereza del territorio, de la que hacíamos mención al comienzo del estudio, y la consiguiente dificultad en las comunicaciones.

29 Sumario del Concilio Provincial de Lima de 1567, cap. 105, fol. 9 r." AGI, Patronato, 248, R. 3.

30 Huaman Poma de Ayala: Nueva Corónica ..., pág. 881. 
19

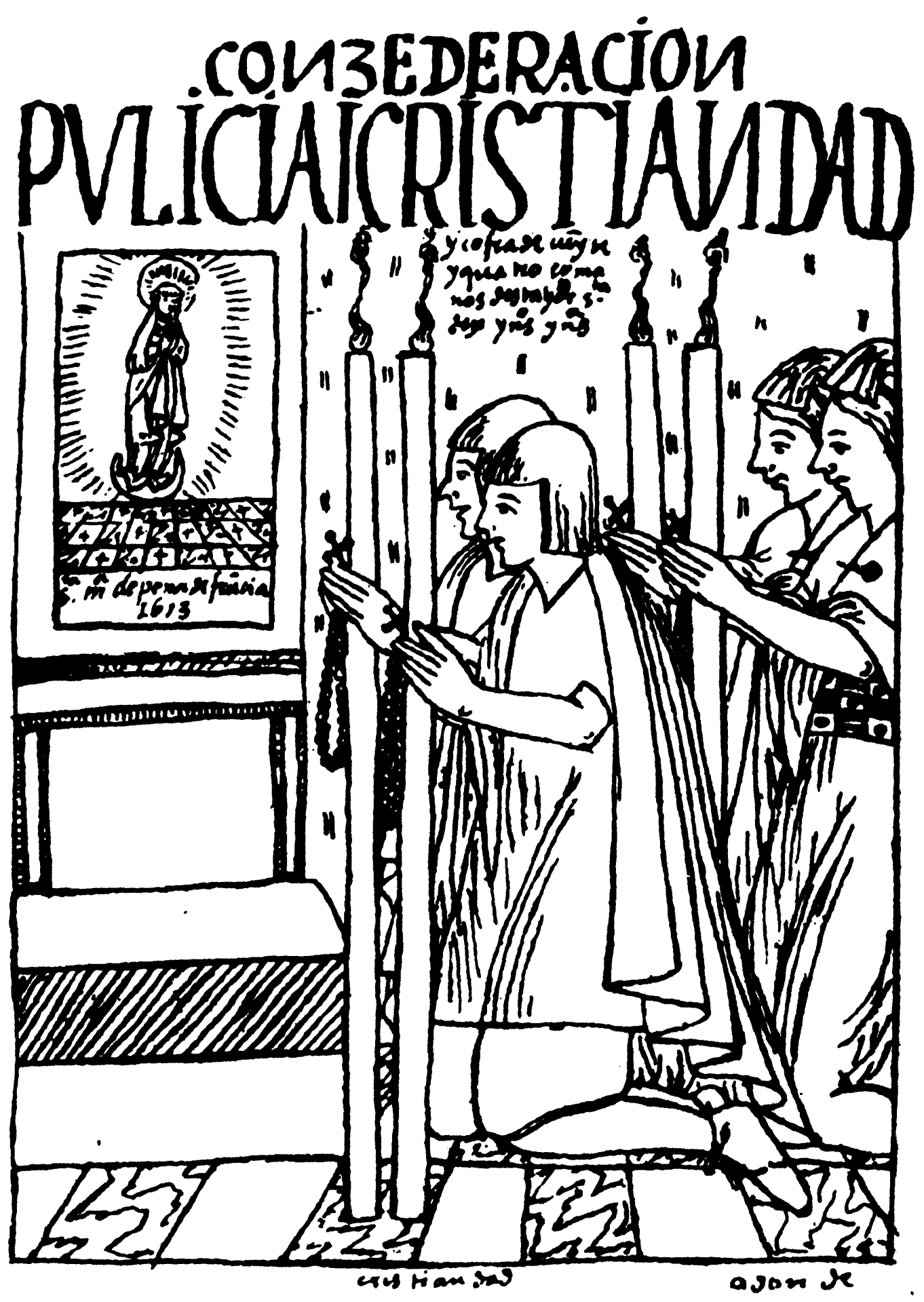

Cofrades indios de Sta. M." de la Peña de Francia. Felipe Huaman Poma de Ayala: Nueva Corónica... pág. 919. 
Todo ello eran factores que otorgaban una enorme autonomía al cura local de cada pueblo para llevar a cabo su misión adoctrinadora, con lo que en la práctica todas las comunidades indígenas vinieron a pasar a un sometimiento declarado a esta figura del doctrinero. La creación de cofradías en las doctrinas y pueblos de indios, que se había convertido en el arma espiritual preferente usada por la Iglesia en sus tareas doctrinales, como vimos ya con anterioridad, devino así "en un medio de dominio eclesiástico sobre la vida del indígena". ${ }^{31}$ Comenzó de esta forma un importante fenómeno expansivo de fundación de cofradías, impulsado por el clero local, que las haría presentes en un alto porcentaje de las doctrinas de indios; habíamos avanzado ya la cifra de 297 cofradías existentes en el Arzobispado de Lima en 1619. ${ }^{32}$ Tal situación llegó a provocar las denuncias de la propia jerarquía diocesana, estipulándose en el Sínodo de Huamanga:

"Por quanto somos informados que muchos curas, así de españoles como de yndios, por disimular su codicia con título de piedad y devoción, procuran que en sus yglesias aya muchas cofradías, ordenamos y mandamos que de aquí adelante no se augmente ninguna cofradía...". ${ }^{33}$

Un aspecto decisivo a tener en cuenta en todo este proceso era la importancia de las funciones económicas que pasaron a desempeñar las cofradías indígenas. El pago de las obligaciones de la iglesia y de las fiestas y misas encargadas por las cofradías, con las que cumplian con sus deberes sacramentales, se convirtió en la base del sustento y mantenimiento del clero local, llegando a suponer tales derramas una tercera parte de los ingresos totales de la Iglesia.

Para satisfacer este tipo de tributos, aparte de disponerse de las cuotas pagadas por sus miembros, las cofradías disponían de una serie de bienes raíces, tierras y ganado, definidos a veces como parcos e insuficientes para el sostenimiento del culto, a pesar de que ocasionalmente llegaran a suponer elevados capitales. Generalmente, los escasos medios agropecuarios que ofrecían las comarcas serranas andinas privaron a las cofradías peruanas de los grandes bienes de los que llegaron a disfrutar,

31 Orellana, Sandra L.: "La introducción del sistema ...".

32 Ver nota 24.

33 AGI, Lima, 308. Constituciones Sinodales del Obispado de Huamanga (1629). Libro I. Tít. IV, Cons. 7, fol. 4 r.: Que los curas de españoles e yndios no traten de multiplicar o fundar nuevas cofradías, ni señalen Alferes ni pendoleros para las fiestas. 
por ejemplo, en la zona mesoamericana. Estas tierras y ganados se entendían como pertenecientes a la cofradía, beneficiándose del trabajo comunal de todos sus miembros; de aquí se derivaban sus ingresos para el cumplimiento de las funciones cívico-religiosas que venían cumpliendo las cofradías en la comunidad. Se habla así en la documentación de rentas provenientes de árboles frutales, viñas y algunas sementeras que hacen los hermanos, aunque ninguna de ellas de gran cuantía; también se indica el número de cabezas de ganado de las que obtenían las cofradías sus rentas, cuantitativamente mucho más importantes que las tierras, poseyendo algunas seiscientas cabezas de carneros y ovejas de Castilla y catorce vacas, y alcanzando otras incluso las mil cabezas de ganado ovejuno. ${ }^{34}$

El control eclesial sobre las cofradías quedó encomendado en las doctrinas de indios al clero local. La autoridad que pasaron así a ejercer los curas en sus doctrinas y pueblos se expresaba en la práctica cotidiana con el nombramiento de los alcaldes y alguaciles, que se convirtieron en "meros agentes eclesiásticos, mediante los cuales los curas ejercían una autoridad que aesbordaba los límites de su jurisdicción, cuestión nada extraña cuando aún faltaba una organización civil establecida y estable". ${ }^{35}$ De la misma forma, los doctrineros nombraban a los mayordomos de las cofradías, cargos para los que eran normalmente designados los caciques y principales del pueblo, y que solían ser a un tiempo los mismos alcaldes y alguaciles que desempeñaban las tareas de organización civil de la comunidad. Se incidió, además, muy especialmente en el cuidado de los capitales y bienes manejados por ellas, de donde se seguían fuertes intereses y una utilidad reconocida para la Iglesia:

"Los bienes y ganados de las Yglesias, Hospitales y Cofradías de pueblos de yndios estarán a cargo de los propios curas, siendo clérigo, y del caçique o mayordomo yndio que estuviere señalado por nos o nuestros visitadores; porque de aver estado a cargo de otros avemos entendido ha venido a mucha disminución....". 36

34 Ver nota 24.

35 Heras Díez, Julián: "La evangelización del Perú en el siglo XVI", en El mundo andino en la época del Descubrimiento. Lima, 1990. pág. 121.

36 AGI, Lima, 307. Constituciones Sinodales del Obispado de Truxillo (1623) Sesión 5.", cap. 6, fol. 7 r. ${ }^{\circ}$ Que los bienes de las Yglesias, Hospitales y Cofradías sean a cargo de los curas $y$ vicarios de las doctrinas, $y$ estando en poder de otros tengan cuydado de visitarlos y tomarles quentas a menudo. 
Sin embargo, se dispusieron ciertas medidas por parte de la autoridad eclesiástica para evitar, en la medida de lo posible, el enraizamiento permanente de algunos de estos cargos en connivencia con los curas:

“...ningún cura de yndios, en las fiestas de cofradías o otras qualesquiera que sean, nombre o señale de un año para otro alférez o pendolero, sino que el mismo día de la fiesta él mismo, de su mano, dé el pendón al que le pareciere ser más digno de llevarlo, y por ningún caso vaya a comer a casa del dicho pendolero, ni reciva dél regalo alguno...". ${ }^{37}$

El control directo sobre los bienes de las cofradías que recaía en el doctrinero, a cuyo cargo quedaban frecuentemente, fue motivo suficiente para la exacción continua. El pago de tributos injustificados, la exigencia de presentes y la prestación de servicios personales por parte de los indios acabaron implantándose como práctica común, tal y como pone de relieve Huaman Poma de Ayala:

“...como los dichos padres de las doctrinas de cada pueblo toman hazienda de las dichas yglesias o de los cofrades del hospital, y se las llevan, deziendo que les ayuda, y lo gasta...". ${ }^{38}$

Tales abusos y desmanes de los doctrineros llegaron a recogerse en diversas disposiciones sinodales, de donde venía la preocupación por someter a norma el desmedido control económico que los curas locales efectuaban sobre las cofradías. Así, el Sínodo de Lima de 1613 preceptuó claramente:

"Y porque algunos [curas] quieren paliar sus grangerías con dezir que para sus Iglesias, o las Cofradías, prohibimos que aunque sea con este color no usen de ellas, sino que dexen a los Indios que a su voluntad hagan lo que les pareciere (...) Y ninguno se ha de poder encargar de administrar ni tomar en sí las viñas o heredades que tubieren sus Iglesias o las Cofradías, y dexarán que entiendan en ellas otras personas de satisfacción". ${ }^{39}$

De la misma forma, y pocos años después, el Sínodo de Huamanga seguía preceptuando:

37 Ibídem.

38 Huaman Poma de Ayala: Nueva Corónica ..., pág. 565.

39 Sínodo Diocesano de Lima de 1616. Título De Constituonibus, Cap. IV. Publicado por Lobo Guerrero, Bartolomé y Arias de Ugarte. Fernando: Sínodos de Lima de 161.3 y 16.36. Madrid, 1987. 
"Y en la celebración de las dichas cofradías y sus fiestas, el cura no pida ni compela a los cofrades a que le den presente alguno de vino, aves, carneros, ni otra cosa alguna, so pena de volberla con el quatro tanto". ${ }^{40}$

No obstante, la presión económica y fiscal a que se vieron sometidas en general las cofradías indígenas por parte de la Iglesia, y no sólo por el clero local, llegó a ser abrumadora. Ya en fecha temprana, la obligación que impuso el Concilio de Trento de levantar seminarios en todos los obispados, para lo que se preceptuó el cobro del tres por ciento de todas y cualesquiera rentas eclesiásticas, motivó ciertamente no pocas críticas, tanto desde ámbitos civiles como propiamente religiosos. Al respecto escribió el virrey a S.M. lo siguiente:

"En lo que toca a cofradías corren algunas de las raçones dichas, y que la tierra es nueba y se comiença a fundar en devoçión, y conviene avidar a esto y no agravar a los cofrades, maiormente si son indios, que sería possible dejarlas por esta causa". ${ }^{41}$

En 1605, a modo de ejemplo, se pretendió que las contribuciones económicas de los indios hacia sus cofradías se empleasen en obtener la bula de la Santa Cruzada, a lo que argumentó el virrey:

"Estas cofradías y grangería para los gastos que en ellas se hazen son en mui poca cantidad, y aunque sea para botos y ministerios de la iglesia se les impide a los indios el hazerlos sin mucha limitaçión; y consideradas las cargas y oppresión en que biven y el poco tiempo que les sobra aún para sembrar lo que preçissamente an menester para su sustento, tengo por imposible que por este camino aya medio justo y efetivo para lo que se pretende". ${ }^{42}$

Tales funciones económicas permitían, al tiempo que sujetaban a la cofradía a la autoridad eclesiástica, una ligera tendencia a su autonomía en los ritmos vitales y de organización cotidianos, ya que en la mayoría de los casos los curas locales satisfacían sus deseos de presencia en el pueblo y de mantenimiento de sus parroquias a cambio de los ingresos arrojados por las cofradías, mostrando una cierta dejación en cuanto al funcionamiento interno de las mismas.

40 Constituciones Sinodales del Obispado de Huamanga. Ver nota 33.

41 AGI, Lima, 32, n." 8, fol. 3 v." El virrey a S.M., 25 de abril de 1588.

42 AGI, Lima, 35. Libro 1, n." 25, fol. 41 r." 
De esta forma, solapadamente, las cofradías se revelaron a un tiempo como un poderoso instrumento de vertebración social, favoreciendo la asociación comunal y la integración en torno a ellas. Los grupos tribales y de parentesco, como base de la organización socio-política entre las culturas precolombinas, habían entrado en un proceso de disolución con la puesta en práctica de las medidas colonizadoras de reducciones de la población en pueblos de indios, dada la dispersión geográfica de los enclaves indígenas. Este vacío en las formas de integración de los diversos grupos sociales dentro de la nueva cultura sincrética parece que fue llenado, en parte, por la institución de la cofradía, tomando plenamente estas funciones en los pueblos y parroquias en los que los españoles reagruparon a la población indígena para su reordenamiento político. Se evitó su desarraigo, creándose nuevos vínculos y lazos de unión entre los miembros de la comunidad. Así, haciendo corresponder sus estructuras ritual y social, las cofradías pasarían a ejercer las funciones de importancia para la vida del pueblo, como las políticas y las económicas. ${ }^{4.3}$

Habíamos comentado ya anteriormente la identidad jerárquica que existió por lo común entre los mayordomos, jefes y oficiales de las cofradías, con los jefes de linaje, caciques y principales de la comunidad, aunándose así las estructuras cívico-sociales y religiosas en la jerarquía ritual de las cofradías. Este sistema permitió, en gran medida, una supervivencia en las formas de organización social indígena, que mantuvo su validez sin apenas obstáculos dentro del sometimiento al control de los colonizadores hispanos. De aquí emanaría la estructura ritual sincrética que ha venido caracterizando de forma virulenta las expresiones populares de las culturas andinas.

\section{El control reformador de las cofradías}

No obstante, el Concilio de Trento dotó a los obispados de una serie de efectivos instrumentos de control para verificar el conocimiento de la realidad de la Iglesia y emprender una febril actividad organizadora y normativa, depurando excrecencias ajenas a una renovada doctrina de la que se había convertido en su principal valedora. De es-

43 Rodríguez Mateos, Joaquín: "Apuntes para una aproximación a la cofradía en América”, en Rábida, n." 7, Huelva, marzo de 1990. 
ta forma, visitas a la diócesis, concilios provinciales y sínodos diocesanos se sucedieron de forma habitual e importante entre los últimos años del siglo XVI y los primeros del XVII como las armas principales para la defensa e impulso de una Iglesia en actitud combativa hacia su propia reforma interior. En estos mismos documentos, dimanados del espíritu del Concilio, nos basaremos, pues, para analizar la situación de las cofradías peruanas.

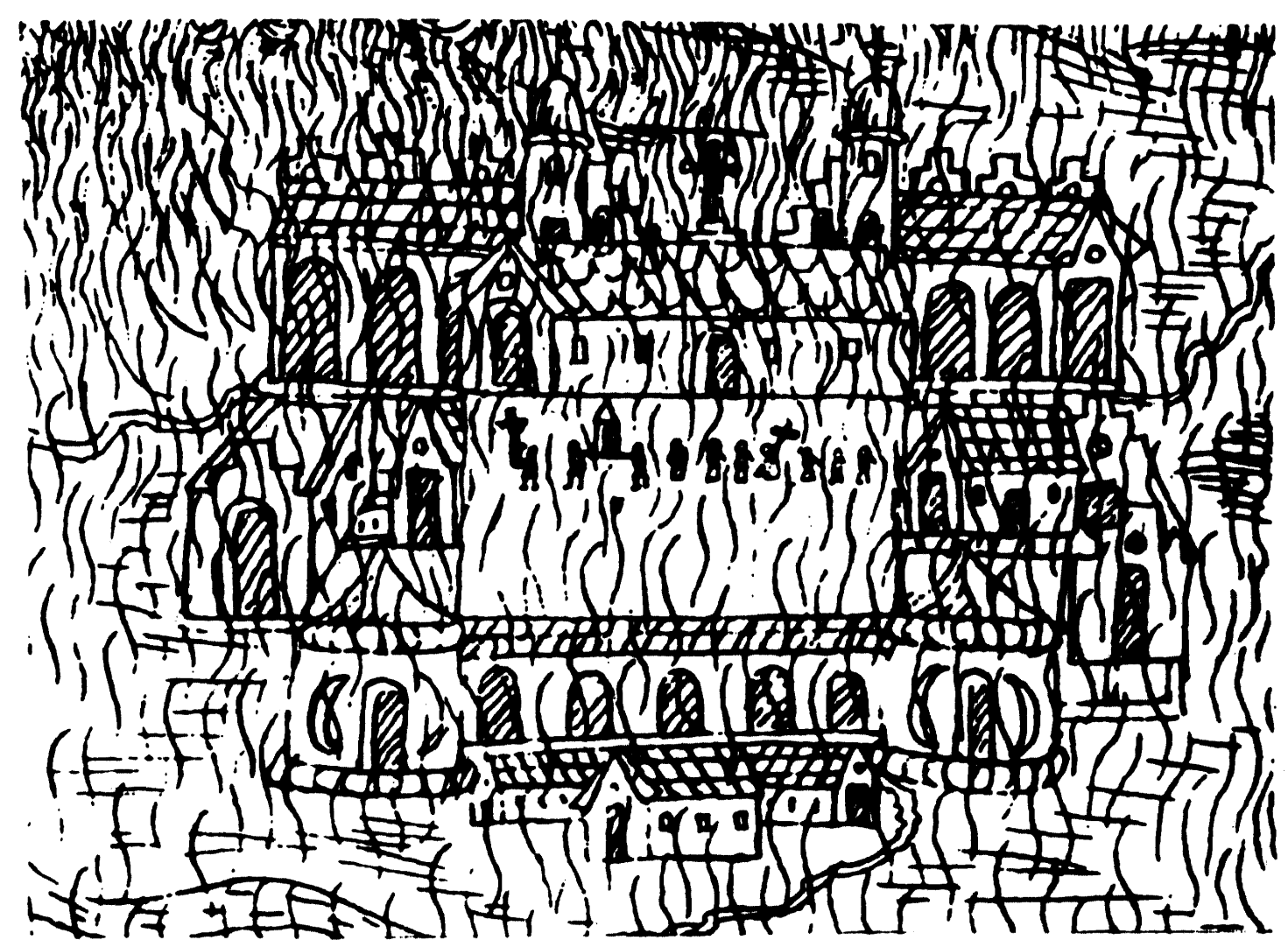

Procesión de disciplina en la ciudad de Arequipa durante una erupción volcánica, que "con la ayuda de dios y de la virgen sta. ma. se aplacó". Felipe Huaman Poma de Ayala: Nueva Corónica... pág. 1.053.

A pesar del tardío auge de las cofradías en Perú, cuyas causas hemos avanzado ya anteriormente, existían algunas fundadas ya desde 1540 con la consolidación de la población hispana en los centros urbanos, donde, en palabras de Olinda Celestino, "el nacimiento de las cofradías es muy precoz ... casi paralelo a la instalación colonial". ${ }^{44}$ De todas formas

44 Celestino y Meyers: Las cofradias en el Perú..., pág. 110. 
supondría para entonces aún una expresión religiosa de pequeña entidad dentro del conjunto de un obispado como el de Lima, en período de asentamiento y consolidación. Sin embargo, el último tercio del siglo comenzó a manifestarse ya ciertamente activo en cuanto a la fundación de cofradías y a su extensión por el territorio litoral peruano, constituyendo un fenómeno cada vez menos ligado a su origen urbano.

El Segundo Concilio Provincial de Lima, de 1567, convocado para adaptar la iglesia peruana a los decretos tridentinos, dedicó ya una cierta atención al fenómeno de las cofradías, la que se vería complementada con las disposiciones del Tercer Concilio Provincial, en 1582-1583. En todo el trasfondo de estas constituciones existía una clara intencionalidad reformadora - Que las coffadrías las visite y reforme el ordinario - ${ }^{45}$ que pone de manifiesto una realidad de este fenómeno lo suficientemente pujante, alejado a veces de los fines concretos para los que se fundaron y fomentaron las propias cofradías, como para merecer la atención de la Iglesia y las disposiciones conciliares. En el fondo, la incomprensión por parte de las cofradías de su adscripción al ámbito jurisdiccional del derecho eclesiástico, o bien la falta de una total aceptación de tal dependencia, motivó unas tensas relaciones y una cierta conflictividad con la jerarquía que impulsarían en mayor medida la adopción de las medidas de control que venimos exponiendo. A un tiempo, este cuerpo legal-doctrinario constituiría la base normativa sobre la que habrían de ajustarse las futuras fundaciones por todo el Arzobispado.

Las cofradías, como fundaciones populares, eran sensibles de forma especial a los vaivenes religiosos de la mística social de fines del Quinientos, catalizando las expresiones más diversas en rituales y ceremonias públicas. A pesar de que en las Indias las cofradías fueron utilizadas en mayor grado como instrumentos adoctrinadores de la naciente pedagogía barroca de manos de la Iglesia, el peligro de las pervivencias ceremoniales prehispánicas, solapadas en estas instituciones, muchas de ellas en manos de los propios indígenas y con evidentes funciones que traspasaban el umbral de lo religioso, exigía un control más cercano de las mismas que las privara de sus aspectos más puramente profanos.

De este modo, las disposiciones conciliares se centraron, fundamentalmente, en los siguientes aspectos: control de los estatutos de las cofradías y de sus fundaciones; reducción del número de cofradías ya

45 AGI, Patronato, 248, R. 3. Sumario del Concilio Provincial de Lima de 1567. Capítulo 85. 
existentes, lo que habla del ritmo de su crecimiento para este período; control de sus capitales y cuentas, y control de su organización, de sus rituales sociales y sus manifestaciones públicas. Se trataba, en suma, de velar por la pureza doctrinal y religiosa que suponía la puesta en práctica del aparato conciliar.

A todo este conjunto de medidas de control vendría a sumarse una creciente presión fiscal sobre las cofradías por parte de la Iglesia, que contribuyera al mantenimiento del clero local - del que se convirtieron en una de sus principales fuentes de ingresos- $y$, en alguna manera, al de la propia organización eclesiástica.

Obviamente, el instrumento fundamental de información y control se centró en la visita, estableciéndose sus objetivos en la Instrucción para visitadores emanada del Tercer Concilio Provincial de 1582-1583:

"Yten, por el mismo orden visitará hospitales, cofradías, hermitas, escuelas de muchachos, acerca de la doctrina que les enseñan, y hagan grande escrutinio en los abusos de las cofradías, limpias de ellas, y de lo profano que tienen las dexe bien reformadas y concertadas en el servicio de Dios, conforme al Concilio". ${ }^{46}$

- Con respecto al primero de los aspectos reseñados anteriormente, el control de las fundaciones religiosas, es de destacar cómo la Iglesia se reservó el derecho jurisdiccional de sancionar los estatutos y constituciones de las cofradías. Con su necesaria aprobación eclesiástica y la consiguiente obtención de la preceptiva licencia, se intentó poner coto a un desarrollo incontrolado de éstas por todo el obispado, tanto en manos de los indios como de los propios españoles, que pudiera llegar a devenir en un espíritu ajeno al propio de la doctrina. A este respecto son especialmente completas las Constituciones Sinodales de 1570 del vecino obispado de Quito:

“...por ende, ordenamos y mandamos que de aquí adelante no se erijan cofradías sin nuestro espreso consentimiento, o de nuestros vicarios en nuestro nonbre, pero reservamos la conformaçión dellas a nos, o a quien nuestro poder uviere. E si algunas estuvieren hasta agora elegidas, no se use dellas hasta que por nos sean vistas y exsaminadas...". ${ }^{47}$

46 AGI, Patronato, 248, R. 3. Instrucción para visitadores, n." 20. 1583.

47 AGI, Patronato, 189, R. 40. Sínodo Diocesano de Quito de 1570, capítulo 33: De las Constituciones que deben guardar los curas de los pueblos de españoles de este obispado. 
Los medios utilizados para evitar el funcionamiento ordinario de las cofradías en tanto careciesen de la aprobación diocesana, pasaban por el relajamiento de los juramentos habituales realizados por los cofrades a su ingreso, práctica empleada también ya en la Península en esos años para los mismos efectos. ${ }^{48}$ Tanto el referido Sínodo de Quito de 1570 como el de 1594 así lo expresan:

"En las cofradías que oviere estatuto que el que entra aya de jurar los estatutos y constituçiones dellas, no se guarde, ni los cofrades juren esto ni otra cossa alguna, y por esta Constituçión relajamos todos y qualesquier juramentos que hasta aquí se uvieren hecho, y damos facultad a los curas para que dellos los puedan absolver...". ${ }^{49}$

- Medida paralela a ésta fue la reducción del número de cofradías ya existentes, tomada por vez primera en el Tercer Concilio Provincial de Lima, de 1583, lo que denotaba una inquietud alarmante en el seno de la jerarquía diocesana hacia el desarrollo y expansión de este fenómeno:

"Las cofradías se visiten por los ordinarios, y en quanto sea posible se reduzcan a menor número, y no den licencia para ordenarse otras de nuevo sin causa de mucha ymportancia". ${ }^{50}$

Tales afanes de reducción se siguen prescribiendo igualmente en años sucesivos, tal como lo hace el Sínodo de Quito de 1594, so color de la conflictividad inherente a la organización de las propias cofradías:

"Somos informados aver muchos exçessos y ofensas de nuestro Señor entre yndios por la mucha cantidad que ay de cofradías, y los muchos abusos que por este respecto tienen, y que convendría reduzirlas a menos, y señalarles sus lugares en las procesiones para quitar diferencias y escándalos.....51

48 Sínodo de Sevilla de 1586. Lib.l, Título De constituonibus. Capítulo 2, Que no se hagan cofradias para exercicio de obra pía, sin licencia del Ordinario.

49 AGI, Quito, 76, n." 35. Constituciones Sinodales del Obispado de Quito, de 1594. Capítulo 58: Sobre estaturos de cofradias.

50 AGI, Patronato, 248, R.3. Concilio Provincial de Lima de 1583. Act. III, Capítulo 44: De las cofradias. Traducción publicada en Historia de la Iglesia de España en Perú, vol. III, n." 12. Sevilla, 1945.

51 AGI, Quito, 76, n.” 35. Sínodo de Quito de 1594. Capítulo 42: Sobre las cofradias, $y$ que se reduzgan a menor número por los inconvinientes. 
A pesar de todas estas disposiciones, el número de cofradías fue incrementándose a lo largo de los últimos años del siglo y del primer cuarto del XVII, apareciendo recogidas en la relación que el arzobispo de Lima envía a S.M. en 1619 un total de 297 cofradías en todo el Arzobispado, lo que da una idea de la magnitud y desarrollo de este fenómeno religioso. ${ }^{52}$ No será hasta el Sínodo Diocesano de Lima de 1636 cuando se regule y fije el número de cofradías que deberían existir en las iglesias y monasterios de la diócesis:

"Y haviendo experimentado en las visitas que emos hecho el grande inconveniente que hay en que aya tanto número de las dichas Cofradías, y que en ellas se saquen pendones, mandamos que (...) en cada Iglesia o Monasterio no aya más de tres cofradías que pidan limosna por las calles públicamente. Y en las Iglesias de los pueblos de españoles pueda haver otra cofradía de Indios, y otra de negros (...), y aquéllas solas puedan pedir limosna públicamente, y no más; y en los anexos de las Doctrinas principales no pueda haver más de una Cofradía". ${ }^{53}$

- En lo concerniente al control económico de las cofradías, la Iglesia se arrogó el papel de administradora de los bienes de las mismas en tanto que "bienes eclesiásticos", ${ }^{54}$ bien bajo el control directo del religioso o doctrinero, fundamentalmente en los ámbitos rurales, o por la acción delegada de los mayordomos, elegidos o nombrados por los propios religiosos. Se proveyeron diversas disposiciones para la preceptiva presentación de sus cuentas ante la autoridad eclesiástica y la aprobación de las mismas, como las expuestas en el Concilio Provincial de Lima de 1567:

"Que las coffadrías las visite y reforme el ordinario, y se le dé quenta de los estatutos y limosnas que uviere, y los maiordomos prometan al principio de su officio ante el obispo de dar la dicha quenta". ${ }^{55}$

A esta situación contribuyó además, de forma importante, el elevado volumen de capitales y posesiones manejados por las cofradías indígenas en las comunidades y pueblos de indios, lo que originó se fijase una frecuente periodicidad para tomar las dichas cuentas:

52 Ver nota 24.

53 Sínodo Diocesano de Lima de 16.36. Lobo Guerrero y Arias de Ugarte: Sínodos de Lima....

54 Cfr. Celestino y Meyers: Las cofradias en el Perú..., pág. 112.

55 AGI, Patronato, 248, R. 3. Sumario del Concilio Provincial de Lima de 1567. Cap. 85, fol. 7 v." 
"los curas, so pena de quatro pesos, tomarán quentas cada quatro meses a los mayordomos de las cofradías, porque con la dilación no se oculten sus bienes". 56

Este control se pone de manifiesto en numerosas ocasiones a lo largo de la documentación, argumentándose por el propio clero el hecho de que las cofradías tenían al respecto "...en todo tanta razón y quenta, que quando la dan de su libro al provisor la alla siempre muy puntual". ${ }^{57}$

En esta misma línea se situó el control de las demandas y limosnas que constituían parte importante de los ingresos de las cofradías, fundamentalmente en los ámbitos urbanos. Éste fue un fenómeno expansivo, que llegó a inundar la vida cotidiana de las ciudades como un medio público para atender el culto y la asistencia mutuas. Una muestra de ello se encuentra en esta carta del arzobispo de Lima al rey, de 1564:

"En esta çibdat se ynstituyó, avará ocho años, una hermandad para que con las limosnas que se juntasen y los cofrades tuviesen orden y cuydado de pedir, fuesen socorridos los pobres vergonçantes, y çierto se a hecho y haze mucho bien, porque de ordinario se reparten cada mes trezientos pesos..... 58

Pero bajo esta situación se aglutinaban generalmente intereses diversos y fines dispares, que quedaban solapados bajo el pretexto común de lo religioso en tal ambiente de piedad colectiva, canalizándose a través de la limosna, en su conjunto, fuertes sumas dinerarias. El Cabildo de la ciudad de Lima llegó a presentar así al Concilio Provincial de 1583, entre otros de los aspectos considerados más necesarios a tener en cuenta para su reforma, el que se pusiera "orden y límite cerca de las limosnas que se piden para diversas obras y cofradías, y que no se pidan más de las necesarias, que son la charidad, caxa del Santísimo Sacramento, Animas del Purgatorio, ospitales, pobres y bergonçantes, redempción de cautibos...". 59

El Concilio ordenó así la regulación normativa de demandas y limosnas, que pasaron a quedar bajo el control eclesiástico con la necesaria obtención previa de licencia:

56 Constituciones Sinodales del Obispado de Huamanga. Ver nota 33.

57 Joseph Tiruel, rector de la Colegial de San Pablo, de la Compañía de Jesús. Ver nota 5.

58 AGI, Lima, 300. El arzobispo de Lima a S.M., 18 de marzo de 1564.

59 AGI, Patronato, 248, R. 15, fol. 4 v." Memorial presentado por el Regimiento y Cabildo de la Ciudad de los Reyes al Concilio Provincial de 1583. 
“...ni para las |cofradías| ya ordenadas, permitan que se pida limosna por el pueblo, sino en domingos y fiestas, y so pedida primero licencia...". ${ }^{6)}$

A pesar de tales disposiciones, a comienzos del siglo XVII el conjunto de las limosnas manejadas por las cofradías limeñas rondaba sobre cantidades algo superiores a los treinta mil pesos anuales, lo que suponía un fenómeno activo, pujante y poco afectado por tales normativas diocesanas.

- La presencia eclesial llegó a ser una constante en la vida ordinaria de las cofradías, siguiendo el espíritu de Trento plasmado en su sesión XXII. No había actividad ni reunión de cofrades que no debiera contar con la asistencia y dirección de los religiosos que tuvieran asignados, encomendándoseles de forma especial el control de los cabildos, juntas y elecciones por las diferencias y otros inconvenientes que suelen resultar. " Este carácter pendenciero y litigante de los propios cofrades, heredero del espíritu de emulación y de los afanes de poder y prestigio que anidaban en el seno de toda cofradía, espoleó el celo eclesiástico en el seguimiento de la vida cotidiana de los cofrades. Una expresión de ello se pone de manifiesto en las declaraciones de los religiosos de los conventos de Lima, acerca de las cofradías que residían en sus conventos:

"Asisten siempre a los cavildos y juntas que estas cofradías hazen los dichos padres, y otros religiosos deste convento en su lugar, sin que se les permita hazerlos sin su asistencia... ${ }^{62}$

Hazen otras dos en el año que llaman cavildo, donde eligen sus mayordomos y oficiales y dan orden en sus fiestas y dotrinas, lo qual se haze siempre con mucha paz y conformidad por asistir siempre a ellas el padre que los tiene a cargo". ${ }^{3}$

Tal situación originaba el que estas reuniones y cabildos debieran efectuarse en las propias iglesias, no consintiéndose actos de cofradías en casas particulares. Entre otras de las causas que motivaban esta reclu-

60) Concilio Provincial de Lima de 1583. Ver nota 50.

61 AGI, Lima, 307. Constituciones Sinodales del Obispado de Truxillo (1623), fol. 22 r." Sesión 6."

62 AGI. Lima, 34, libro 6, n." 4I. Fray Agustín de Vega, prior del Convento de Nuestra Señora del Rosario, de la Orden de Predicadores de Lima. Relación adjunta a la carta del virrey del Perú a S.M., acerca de las cofradías de indios y negros existentes en los conventos y monasterios de Lima. 4 de Abril de 1603.

6.3 Joseph Tiruel, rector de la Colegial de San Pablo, de la Compañía de Jesús. Ver nota 5. 
sión en el marco del templo o la iglesia, se encontraba la costumbre habitual de los mayordomos, u otros cargos de ellas, de custodiar y velar la imagen de la cofradía en sus casas por el tiempo de su mandato o mayordomazgo.

Estos jefes de cofradía - los mayordomos o carguyoc- en los pueblos de indios, estaban por lo común relacionados estrechamente con los jefes de linaje, caciques o principales, aunando en ellos las funciones cívicas, sociales y religiosas de la comunidad o el grupo. De esta forma, la posesión de la imagen era a un tiempo un símbolo de poder y una expresión pública del rango. Considerado incluso a la inversa, estos cargos rituales suponían un mecanismo de reconocimiento social, cuya consecución iba a suponer la adquisición de status. Del servicio a la cofradía, y de la generosidad y el desprendimiento hacia ella, se derivaba un prestigio público que facilitaba frecuentemente llegar a los puestos de decisión social de relevancia para la comunidad. En palabras de Luis Valcárcel: "Como en los ritos del potlach, en la fiesta se labra el prestigio permanente del indio, a quien no importa invertir, para conquistarlo, todas sus ganancias pasadas y aún las futuras. El 'cargo' religioso anual es ansiosamente esperado, porque para quien lo ejerce significa la única oportunidad en la vida para labrarse un nombre". ${ }^{64}$

A pesar de que la propia Iglesia designaba en numerosas ocasiones a estos personajes como cabezas de la comunidad para ejercer sus tareas de control, obviamente no estaba dispuesta a admitir unas manifestaciones indígenas de organización socio-política bajo el amparo de las expresiones religiosas. Así se regula, pues, en el Sínodo de Quito de 1594:

"La costumbre que tienen los mayordomos y cofrades de sacar de la yglesia las ymágenes y llevarlas a sus casas, de que resulta indesçençia, prohivimos y mandamos que en ninguna manera se saquen las ymágenes de las yglesias para adereçarlas ni tenerlas los mayordomos en sus cassas ni en otra qualquier manera, y si algunas oviere fuera de las yglesias, se recojan y buelvan a ellas, pues esto es de mayor devoçión y beneraçión que lo que hasta aquí se a hecho y usado". ${ }^{65}$

El fenómeno económico aparejado a la prestación de los cargos se convirtió también frecuentemente en motivo de quejas y denuncias por

64 Valcárcel, Luis E.: Ruta cultural del Perú. México, 1945, págs. 185-186.

65 AGI, Quito, 76, n." 35. Sínodo de Quito de 1594, Capítulo 55: Que no saquen las ymágenes de la iglesia. 
parte del clero; por lo común, se seguía de ellas un fuerte control eclesial - y a veces también civil- para evitar el endeudamiento de los mayordomos a causa del fuerte derroche efectuado en sus cofradías por el tiempo de su mandato. Del mismo modo, el comportamiento ceremonial y las expresiones festivas en las comunidades indígenas fue también, por lo común, objeto de la atención y el control eclesiástico para evitarse, en la medida de lo posible, conductas profanas y poco edificantes con relación a las motivaciones religiosas que justificaban tales fiestas. La denuncia sistemática de las embriagueces indígenas en tales ocasiones llega, incluso, a recogerse en las disposiciones del Sínodo de Huamanga de 1629:

"Y procurarán [los curas] que en tales fiestas no hagan los yndios juntas y borracheras por los grandes daños y offensas de Dios que en ellas se hazen". 66

A este respecto, hay que tener en cuenta el papel funcional que ejercía entre las comunidades indígenas el consumo alcohólico ceremonial. Como explica Roland Anrup, "la conquista modificó la significación de la bebida entre los indígenas, aunque sin llegar a cambiarle su carácter ritual. El beber no era para ellos una forma de «evasión» social sino, muy por el contrario, una de las formas de cohesión comunitaria", 67 a lo que contribuiría, sin duda alguna, el comensalismo ritual inherente a las cofradías.

Con estas medidas de control no sólo se cercenaban actitudes reprochables para la Iglesia, que no podía tolerar tales profanidades en las fiestas religiosas, sino que se minaba una parte del tradicional sentimiento ritual de cohesión comunitaria, sustituyéndose, por el contrario, por una integración en cofradías, estrechamente controladas por el clero.

66 AGI, Lima, 308. Constituciones synodales del Obispado de Guamanga (1629). Libro I, Título IV. Constitución 7, fol. 4 r.": Que los curas de españoles e yndios no traten de multiplicar " fundar nuevas cofradias, ni señalen Alferes ni pendoleros para las fiestas.

67 Anrup. Roland: "Modelos culturales hispánicos y tradición indigena dentro del culto religioso en las haciendas de la Sierra Sur peruana", en Europa e Iheroamérica. Cinco siglos de intercambios. Actas del IX Congreso Internacional de Historia de América de AHILA. Sevilla, 1992. vol. II. págs. 205-218. 